\title{
OPEN Robotic environmental DNA bio-surveillance of freshwater health
}

\author{
Adam J. Sepulveda ${ }^{1}$, James M. Birch ${ }^{2}$, Elliott P. Barnhart ${ }^{3}$, Christopher M. Merkes ${ }^{4}$, \\ Kevan M. Yamahara ${ }^{2}$, Roman Marin III $^{2}$, Stacy M. Kinsey ${ }^{3}$, Peter R. Wright ${ }^{3}$ \& \\ Christian Schmidt ${ }^{5}$
}

Autonomous water sampling technologies may help to overcome the human resource challenges of monitoring biological threats to rivers over long time periods and across large geographic areas. The Monterey Bay Aquarium Research Institute has pioneered a robotic Environmental Sample Processor (ESP) that overcomes some of the constraints associated with traditional sampling since it can automate water sample filtration and preservation of the captured material. The ESP was originally developed for marine environment applications. Here we evaluated whether the ESP can provide reliable, timely information on environmental (e)DNA detections of human and fish pathogens and introduced fishes at U.S. Geological Survey streamgage sites in freshwater rivers. We compared eDNA collected via ESP at high frequency (e.g., every $3 \mathrm{~h}$ ) with manual eDNA collections collected at lower frequency (e.g., weekly). We found that water samples filtered and preserved by ESPs successfully detected the DNA of human pathogens, fish pathogens and introduced fishes. Both ESP and manually collected samples provided similar information about target DNA presence. We suggest that the greatest current benefit of the ESP is the cost savings of high frequency, bio-surveillance at remote or hard to access sites. The full potential of robotic technologies like the ESP will be realized when they can more easily execute in situ analyses of water samples and rapidly transmit results to decision-makers.

Invasive species have serious negative effects on regional and national economies ${ }^{1,2}$. Thus, early detection is a central pillar of most monitoring programs because the earlier an invader is detected, the more likely control efforts will be effective in limiting invader spread and the resulting economic and environmental damages ${ }^{3}$. Environmental DNA (eDNA) sampling has recently emerged as a sensitive, early detection tool because it can detect as little as a single cell from an invasive species by identifying the cellular or extracellular DNA that organisms release into the environment ${ }^{4}$. Despite the ubiquity of eDNA in the aquatic environment, eDNA of targeted taxa is not always well mixed, so high detection probabilities often require intense sampling ${ }^{5,6}$. Therefore, reliable detection requires trained individuals to manually collect water samples over long time periods or across large geographic areas ${ }^{7}$.

Autonomous, robotic water sampling technologies present an opportunity to overcome the temporal and human resource demands associated with eDNA sampling. Autonomous robots placed within the environment can conduct high frequency sampling, regardless of location, weather or the availability of human resources. The Monterey Bay Aquarium Research Institute (MBARI) has pioneered a robotic instrument called the Environmental Sample Processor (ESP) that overcomes the constraints of regular travel and work schedules, safety concerns with high water flows, and adverse weather. The ESP is a robotic device that can be programmed to automate water sample filtration and preservation of the captured material, or homogenize it for immediate analyses in situ (Fig. $1 ;^{8}$ ).

Various iterations of the instrument have been realized over the past 25 years; here we utilized the "secondgeneration" (2G) ESP and its archival capabilities to filter water samples and preserve the collected material for later analysis in the laboratory. Real-time, two-way communication via cellular, satellite or radio allow for

${ }^{1}$ U.S. Geological Survey, Northern Rocky Mountain Science Center, 2327 University Way Suite 2, Bozeman, MT 59715, USA. ${ }^{2}$ Monterey Bay Aquarium Research Institute, Moss Landing, CA, USA. ${ }^{3}$ U.S. Geological Survey, 3162 Bozeman Ave, Helena, MT, USA. ${ }^{4}$ U.S. Geological Survey, Upper Midwest Environmental Science Center, La Crosse, WI, USA. ${ }^{5}$ U.S. Geological Survey, Idaho Water Science Center, Boise, ID, USA. ${ }^{\square}$ email: asepulveda@ usgs.gov 
A

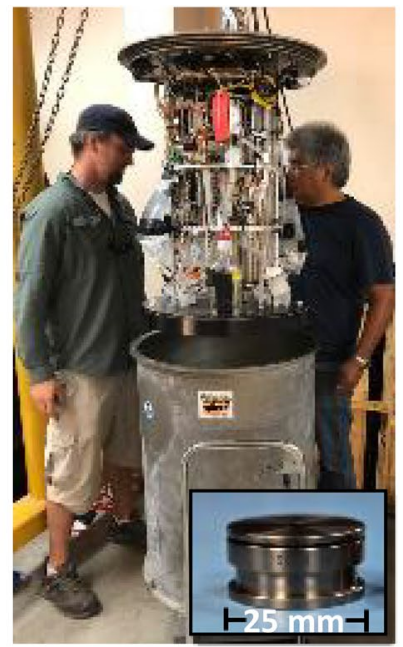

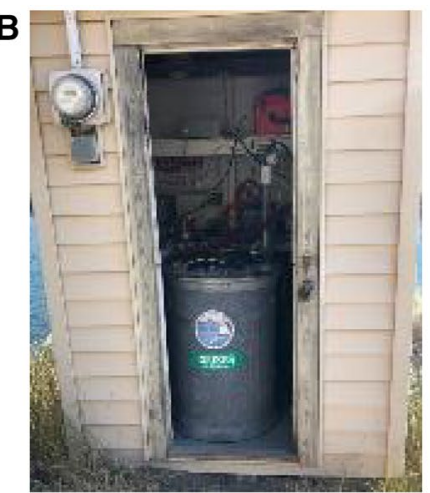

C

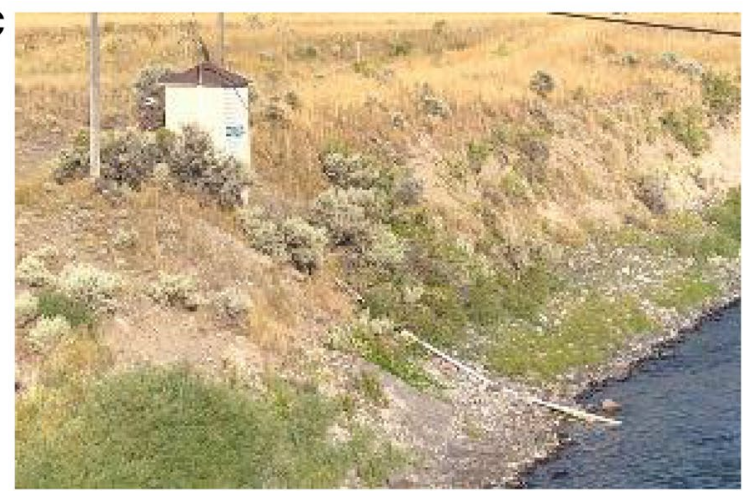

Figure 1. The ESP is an electro-mechanical robot that can autonomously filter and preserve samples. (A) About the size of a 50-gal barrel, the ESP carries 132 'pucks' (inset), each designed to hold $25 \mathrm{~mm}$ filters. (B) The ESP installed in a USGS streamgage station. (C) Streamgage station showing tubing run (white pipe) that contained pump and tubing to deliver stream water to the ESP. The ESP communicated via cell phone, and was powered during the deployment via either line power or portable solar arrays. Photo credits: U.S. Geological Survey.

querying instrument status and augmentation of sampling times or frequency. Although the ESP was originally developed for applications in the marine environment, the ability to operate unattended, over months at a time, made it an attractive option to explore whether the ESP could be helpful to the U.S. Geological Survey (USGS) in carrying out its mission to provide reliable, timely information about the United States' water resources and aquatic health ${ }^{9}$. Here we report the use of the ESP in the field and at USGS streamgage sites to collect eDNA on sample filters and preserve the filters in situ, with analysis taking place after the filters were returned from the field.

With any new technology, one must show its equivalence or purported advantages over the current methods. This study looks at several species of interest and compares eDNA collected via robot with traditional manual collections to determine if a.) both methods capture similar information about target DNA presence/absence, and b.) higher frequency sampling provides more or better actionable information. Our eDNA targets were human and fish pathogens and introduced fish in the Upper Yellowstone River watershed (Montana, USA) and Upper Snake River (Idaho, USA).

\section{Materials and methods}

ESP sample processing. The ESP operated autonomously, needing only power, communications and fluid connections through its waterproof pressure housing (Fig. 1). Prior to sample initiation, the ESP was purged completely with nitrogen to reduce oxidative reactions (i.e., DNA degradation) from occurring. At the initiation of sampling, a puck (Fig. 1A cutout) loaded with filter material was placed within a clamp. Valves open to the outside allowed a syringe to sequentially pull water through the puck. Once the target volume was filtered, or the filter was loaded with biomass (i.e., 'clogged'), filtering stopped and excess water was cleared. Five mL's of RNAlater preservative was then added to the puck, soaking the filter for $10 \mathrm{~min}$ before the excess was evacuated and the puck was returned to storage. Preserved pucks were stored at the ESP temperature, which were similar to ambient air temperatures. The upper limit on the amount of time that an ESP device can operate in the field before DNA quality on a puck is comprised is not known but is at least 21 days ${ }^{10}$. A constant humidity kept the pucks moist, allowing for easy filter removal once the instrument was recovered.

To get water to the ESP, we designed an external sampling module from which the ESP drew water ${ }^{11}$. The sampling module was self-draining, and fed by a submersible pump (WSP-12 V-2 M, Waterra USA Inc., Bellingham, W, USA) installed approximately 0.5 to $2 \mathrm{~m}$ below the river water line at each deployment site. To reduce possible carry-over contamination, the sampling pumps, tubing and external sampling modules were flushed with river water for $10 \mathrm{~min}$ prior to every sample collection. The sampling port of the ESP itself was cleaned with $10 \%$ bleach and a $10 \%$ tween-20 solution between samples. At the end of each ESP deployment, pucks were manually removed and filters were aseptically recovered into $2.0 \mathrm{~mL}$ screw cap centrifuge tubes and stored at $-80^{\circ} \mathrm{C}$ until molecular analyses were performed.

Field deployments. We performed initial ESP feasibility studies in Yellowstone National Park (USA; Fig. 2) in September 2017. Here, our goal was to determine if the ESP could be used to sample DNA of the waterborne protozoa, Naegleria spp., from a freshwater river where these organisms had previously been detected using standard techniques ${ }^{12}$. We filled 60-L sterilized carboys with water from the confluence of the Boiling and Gardner rivers. Carboys were transported to a lab at Montana State University (Bozeman, Montana) and connected to ESP samplers via tubing and syringe pumps. Water was passed through each filter (5- $\mu \mathrm{m}$ Diapore filters) until the filter became clogged; six samples were filtered. 


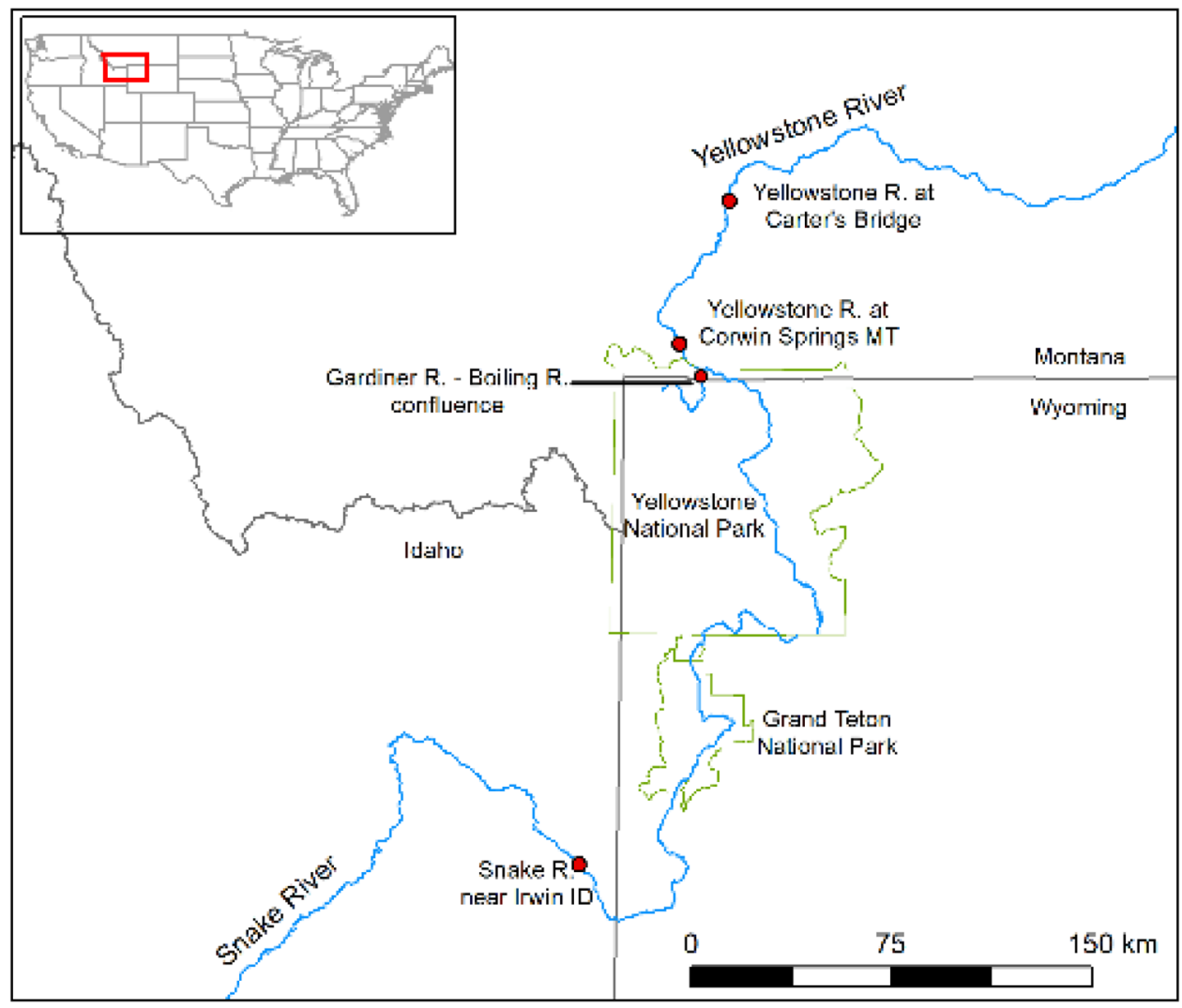

Figure 2. Map of ESP water sampling locations. The inset map shows the location of the Upper Yellowstone River and Upper Snake River in the United States. The larger map shows the sample site locations (filled red circles) on each river relative to Yellowstone National Park and Grand Teton National Park (outlined in green).

We then integrated the ESPs into two USGS streamgages on the Yellowstone River in 2018 and one USGS streamgage on the Snake River in 2019, (Fig. 1B,C) where we tested for DNA of the fish pathogen, Tetracapsuloides bryosalmonae, the causative agent of salmonid fish Proliferative Kidney Disease (PKD). On the Yellowstone River, we installed ESPs at the streamgage near the upstream and downstream extents of a recent PKD outbreak ${ }^{13}$, USGS 06191500 Yellowstone River at Corwin Springs MT and USGS 06192500 Yellowstone River near Livingston MT, described below as Corwin Springs and Carters Bridge, respectively (Fig. 2). On the Snake River, we installed one ESP at the streamgage $1.5 \mathrm{~km}$ downstream of Palisades Reservoir near the upstream extent of a recent PKD outbreak, USGS 13032500 Snake River near Irwin ID. The ESP pucks were loaded with 1.2- $\mu$ m cellulose nitrate filters. We ran two negative controls ( $1 \mathrm{~L}$ of molecular grade water) through the ESP prior to and at the conclusion of deployment to assess for contamination.

Yellowstone River. The ESPs were programmed to collect 1-L samples every $12 \mathrm{~h}$, from Jul 24 to Aug 262018 , and every $3 \mathrm{~h}$ from Aug 27 to Sep 72018 . The average ( \pm 1 SE) volume filtered per sample was $639( \pm 11) \mathrm{mL}$, indicating that most filters clogged prior to reaching the 1-L target volume. Filter samples were collected at ambient air temperatures ranging from 9.6 to $35.8^{\circ} \mathrm{C}(\bar{x}=18.9)$ at Carter's Bridge and $8.3-29.0^{\circ} \mathrm{C}(\bar{x}=17.1)$ at Corwin Springs. We compared T. bryosalmonae ESP detections to those from manually collected grab samples from shore $(6,250-\mathrm{mL}$ samples per site filtered through $1.2-\mu \mathrm{m}$ cellulose nitrate filters) collected at weekly frequencies for the entire length of the ESP deployments and at daily frequencies between Aug 27 and Aug 30. Thus, ESP and manual eDNA samples collected at different temporal intervals ( $3 \mathrm{~h}, 12 \mathrm{~h}$ or weekly) allowed us to evaluate the added value of higher frequency sampling.

We also evaluated the utility of automated high frequency sampling to detect a new invasion by introducing novel DNA of Scomber japonicas (mackerel fish) $100 \mathrm{~m}$ upstream of each Yellowstone River streamgage. On Aug 27, we introduced $3 \mathrm{~kg}$ of canned S. japonicas $100 \mathrm{~m}$ upstream of the water sampling inlet for each ESP. S. japonicas was blended with water, frozen and then placed within metal-wire minnow traps and anchored to the river's bottom with cement pavers. The ESPs were programmed to sample every $3 \mathrm{~h}$ from Aug 27 to Sep 7. Manual grab samples $(600 \mathrm{~mL})$ were collected $10 \mathrm{~m}(\mathrm{n}=3), 100 \mathrm{~m}(\mathrm{n}=6)$, and $400 \mathrm{~m}(\mathrm{n}=3)$ downstream of the S. japonicas in order to test that $S$. japonicas DNA was transported downstream past the water sampling inlet of each ESP. Manual grab samples were collected immediately prior to $S$. japonicas introductions, $3 \mathrm{~h}$ post-introduction and then every $24 \mathrm{~h}$ for 3 days. 


\begin{tabular}{|c|c|c|c|c|}
\hline Target & References & Gene target & Nucleotide sequence $5^{\prime}-3^{\prime}$ & Limit of detection \\
\hline \multirow{3}{*}{ Dreissena spp. } & \multirow{3}{*}{ Gingera et al. ${ }^{16}$} & \multirow{3}{*}{$16 \mathrm{~s}$} & DRE16SF TGGGGCAGTAAGAAGAAAAAAATAA & \multirow{3}{*}{1 copy } \\
\hline & & & DRE16SR CATCGAGGTCGCAAACCG & \\
\hline & & & DRE16SP FAM/CCGTAGGGATAACAGC/MGBNFQ & \\
\hline \multirow{2}{*}{ Naegleria spp. } & \multirow{2}{*}{ Sheehan et al. ${ }^{12}$} & \multirow{2}{*}{ ITS } & NF GAACCTGCGTAGGGATCATTT & \multirow{2}{*}{ NA } \\
\hline & & & NR TTTCTTTTCCTCСССТT ATTA & \\
\hline \multirow{3}{*}{ O. nerka } & \multirow{3}{*}{ Sepulveda et al. ${ }^{7}$} & \multirow{3}{*}{$\mathrm{COI}$} & SSF CTGCCCTTCTCCTTACGATTT & \multirow{3}{*}{1 copy } \\
\hline & & & SSR CAGTGGATCAGAGGAGTGTTAG & \\
\hline & & & SSP AATCGCCATCCTGTTCCTCCTGTT & \\
\hline \multirow{3}{*}{ S. japonicus } & \multirow{3}{*}{ Sassoubre et al. ${ }^{15}$} & \multirow{3}{*}{ COI } & 324F GCTGAACAGTTTATCCTCCCCTCG & \multirow{3}{*}{$0.1 \mathrm{pg} / \mu \mathrm{L}$} \\
\hline & & & 430R CCCAAGGATTGAGGAAACACCTGCTAG & \\
\hline & & & 349P FAM/TGGGAACCTGGCACACGCCGGG/BHQ & \\
\hline \multirow{3}{*}{ T. byrosalmonae } & \multirow{3}{*}{ Hutchins et al..$^{13}$} & \multirow{3}{*}{$18 \mathrm{~s}$} & 1337F CGAACGAGACTTCTTCCTT & \multirow{3}{*}{7 copies } \\
\hline & & & 1426R CTTCCTACGCTTTTAAATAGCG & \\
\hline & & & $\begin{array}{l}\text { 1399P FAM/CCCTTCAATTAGTTGATCTAAACCCCAATT } \\
\text { /IBFQ }\end{array}$ & \\
\hline
\end{tabular}

Table 1. Primers and probes used in this study.

Snake River. The ESPs were programmed to collect 2-L samples every $12 \mathrm{~h}$ from Jul 17 to Sep 09 and then every $4 \mathrm{~h}$ from Sep 10 to Oct 1, 2019. Manually collected grab samples (three, 2-L samples filtered through 1.5$\mu \mathrm{m}$ glass fiber filters) and negative field controls (1, 2-L sample of deionized water filtered through 1.5- $\mu \mathrm{m}$ glass fiber filters) were collected every 2 weeks following methods in Sepulveda et al. ${ }^{7}$. Filter samples were collected at ambient air temperatures ranging from 3.9 to $30.2^{\circ} \mathrm{C}(\bar{x}=20.6)$. To broaden our taxonomic assessment, we tested these samples for T. bryosalmonae DNA, and also for kokanee salmon (Oncorhynchus nerka) and dreissenid mussel (Dreissena spp.) DNA. O. nerka only occur upstream in Palisades Reservoir and at such low abundances that they are not captured by resource managers in annual population surveys ${ }^{7}$. Dreissenid mussels have not yet been observed, but are the principal focus of aquatic invasive species monitoring programs in this region $^{7}$.

Molecular analyses. Filters were removed from the pucks and then shipped frozen to the USGS Upper Midwest Environmental Science Center (LaCrosse, Wisconsin) for DNA extraction and quantitative PCR analyses. Filters were handled and stored in a dedicated room that is physically separated from rooms where highquantity DNA extraction and PCR product or high-quality DNA is handled. We used the FastDNA SPIN kit for soil to extract DNA on samples from the Boiling River-Gardiner River confluence, following modifications described in Barnhart et al. ${ }^{14}$. To extract DNA from Yellowstone River and Snake River samples, we used the Investigator Lyse \& Spin Basket Kit (Qiagen, Hilden, Germany) in concert with the gMax Mini genomic DNA kit (IBI Scientific), following manufacturer's instructions, and eluted in $200 \mu \mathrm{L}$ of buffer. Samples were extracted as site specific batches and one extraction control was collected per batch. We used previously published assays, limits of detection and methods therein for analyses of Naegleria spp. ${ }^{12}$, T. bryosalmonae ${ }^{13}$, S. japonicas ${ }^{15}$, O. nerka ${ }^{7}$, and Dreissena spp. ${ }^{16}$ (Table 1$)$.

We analyzed all samples in four replicate $25 \mu \mathrm{L}$ reactions containing $2 \mu \mathrm{L}$ of template DNA, $1 \times$ Perfecta Toughmix (Quantabio), $400 \mathrm{nM}$ forward and reverse primers, and $100 \mathrm{nM}$ probe. Each plate contained 10 notemplate PCR controls (one for each sample) using $2 \mu \mathrm{L}$ of molecular grade water as the template as well as a standard curve with two replicates of 20,000 and 2,000 copy standards and four replicates of 200 and 20 copy standards. The standards were prepared with synthetic gBlocks (Integrated DNA Technologies) containing the amplicon sequences for each assay. Each sample was also analyzed in three replicates with 200 copies of synthetic gBlock spiked in to check for PCR inhibition. Any sample that indicated less than an average of 60 to 70 copies of targeted DNA in these triplicate samples was considered inhibited. Field and extraction negative controls were analyzed as regular samples. No negative controls amplified.

Analyses. Samples were scored as positive when one or more PCR replicates amplified for the target DNA. We used McNemar's Exact Test to compare binary qPCR data (detection/non-detection) of T. bryosalmonae and O. nerka DNA between ESP and manually collected samples in the Yellowstone and Snake rivers.

\section{Results}

Feasibility study. Naegleria spp. DNA was detected in all PCR replicates from the seven ESP samples, thus demonstrating that the ESP could be used to capture target DNA from a freshwater river where these organisms had previously been detected using standard techniques . Further sequencing analysis is needed to confirm species identity (e.g., N. fowleri), as the assay is only specific to the Naegleria genus.

USGS streamgages. Yellowstone River. T. bryosalmonae DNA was detected in at least one PCR replicate in three of 128 ESP samples at Corwin Springs and in two of 128 ESP samples at Carters Bridge (Fig. 3). Three of 
(a) Yellowstone River 2018

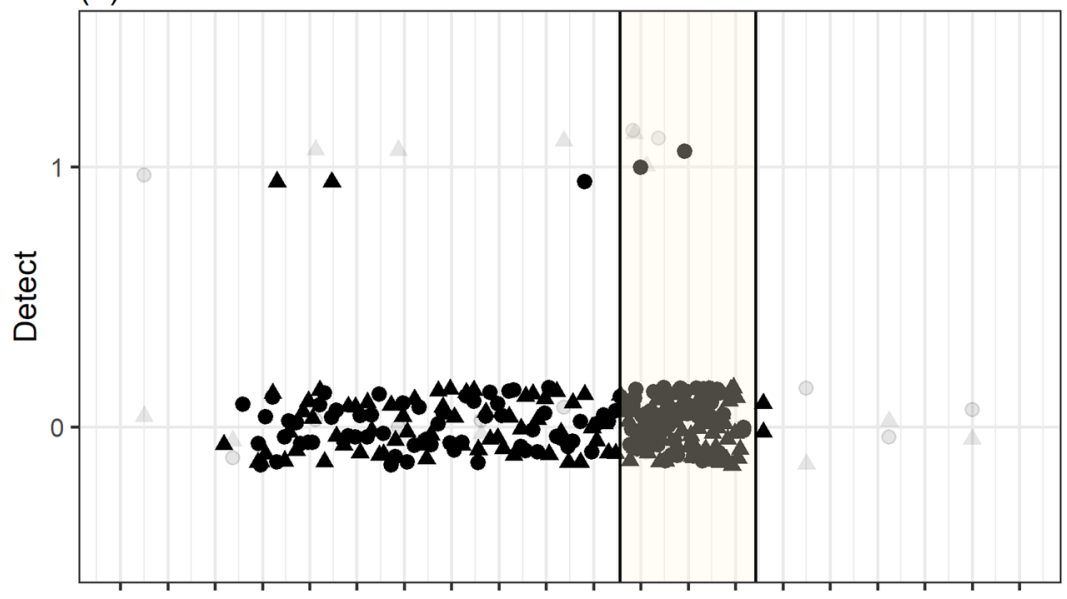

Location

- Carters Bridge

- Corwin Springs

Method

Manual

- ESP

(b) Snake River 2019

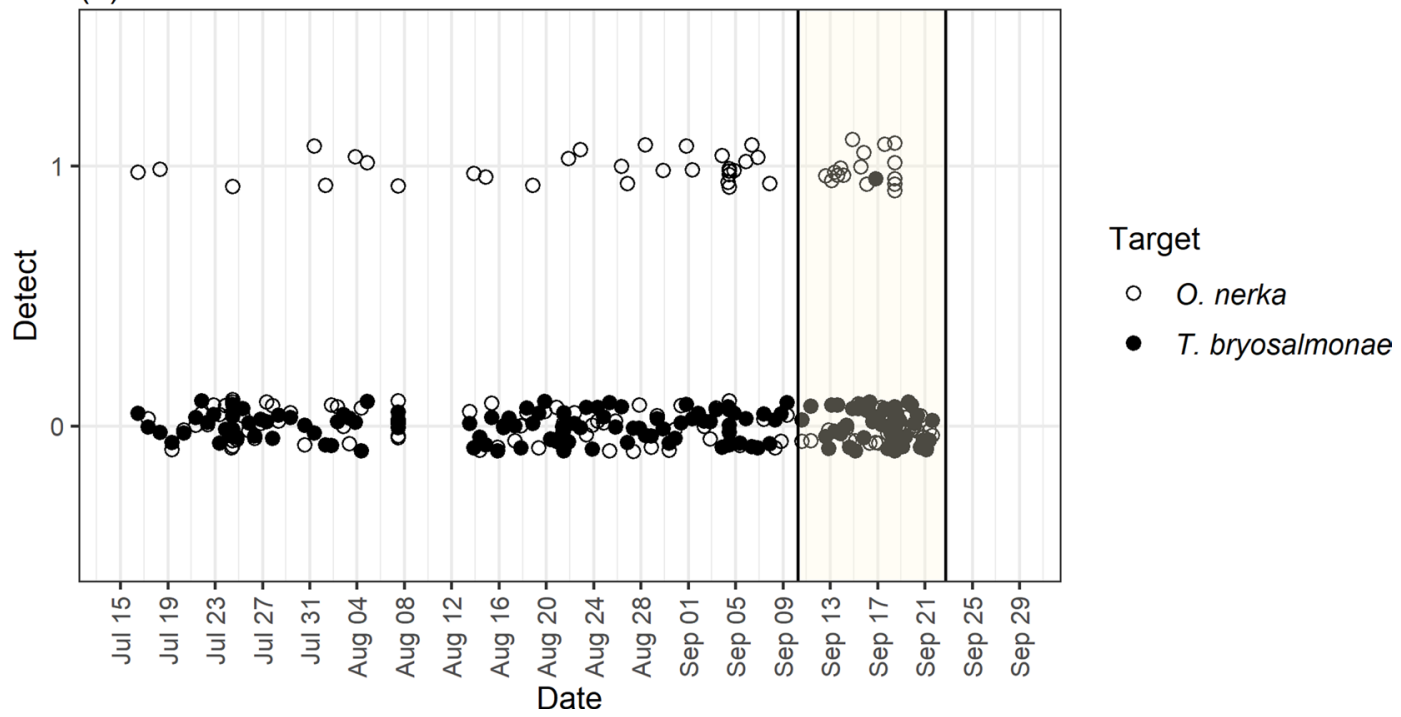

Figure 3. Detection history of ESP and manually-collected grab samples from two locations on the Yellowstone River in 2018 (a) and one location on the Snake River in 2019 (b). Positive detections were those with at least 1 PCR replicate amplified. For clarity, symbols are jittered around the no detection (0) or detection (1) line. T. bryosalmonae DNA was targeted at Yellowstone River locations and O. nerka and T. bryosalmonae DNA were targeted at the Snake River location. Shaded areas indicate time period when samples were collected every $3 \mathrm{~h}$ (a) or $4 \mathrm{~h}$ (b) rather than every $12 \mathrm{~h}$.

these detections occurred during lower frequency sampling (every $12 \mathrm{~h}$ ), which spanned 4 weeks, and two detections occurred during higher frequency sampling (every $3 \mathrm{~h}$ ), which spanned 2 weeks (Fig. 4). Interestingly, detections during the higher frequency period only occurred outside of typical workday times (e.g., 08:00-17:00) when manual samples would not normally be collected (Fig. 4).

Over the same time period, T. bryosalmonae DNA was detected in six of 55 manually-collected samples (Fig. 3). All but one of these detections occurred within a day of an ESP detection. No difference was observed between the detection/non-detection of T. bryosalmonae when comparing the ESP to manual sampling methods $(\chi 2=6, p=0.13, \mathrm{n}=53)$.

S. japonicas DNA was detected in ESP samples at both locations (Fig. 4). At Carters Bridge, S. japonicas DNA was detected in ESP samples $\sim 1$ week after S. japonicas introduction; S. japonicas DNA was not detected in any grab samples from the same location. At the other sampling distances, $S$. japonicas DNA was only detected in grab samples from $10 \mathrm{~m}$ downstream at 3 days. At Corwin Springs, S. japonicas DNA was first detected in ESP samples $\sim 1.5$ days after S. japonicas introduction and then again at 3, 5 and 7 days. S. japonicas DNA was detected in grab samples from this location at 1,2 and 3 days. S. japonicas DNA was also detected in grab samples at $10 \mathrm{~m}$ and $400 \mathrm{~m}$ after only $3 \mathrm{~h}$, at $400 \mathrm{~m}$ after 1 day, and at $10 \mathrm{~m}$ after 2 days. No difference was observed between the detection/non-detection of $S$. japonicas DNA when comparing the ESP to manual sampling methods $(\chi 2=6$, $p=0.29, \mathrm{n}=26)$. 
(a) Yellowstone River 2018

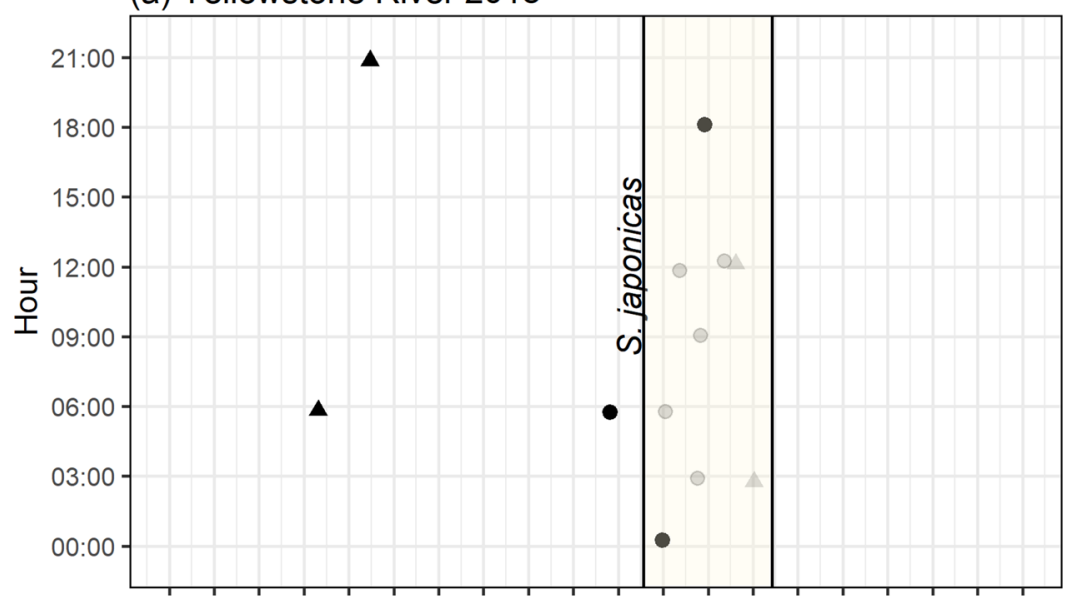

Location

- Carters Bridge

- Corwin Springs

Target

- S. japonicas

- T. bryosalmonae

(b) Snake River 2019

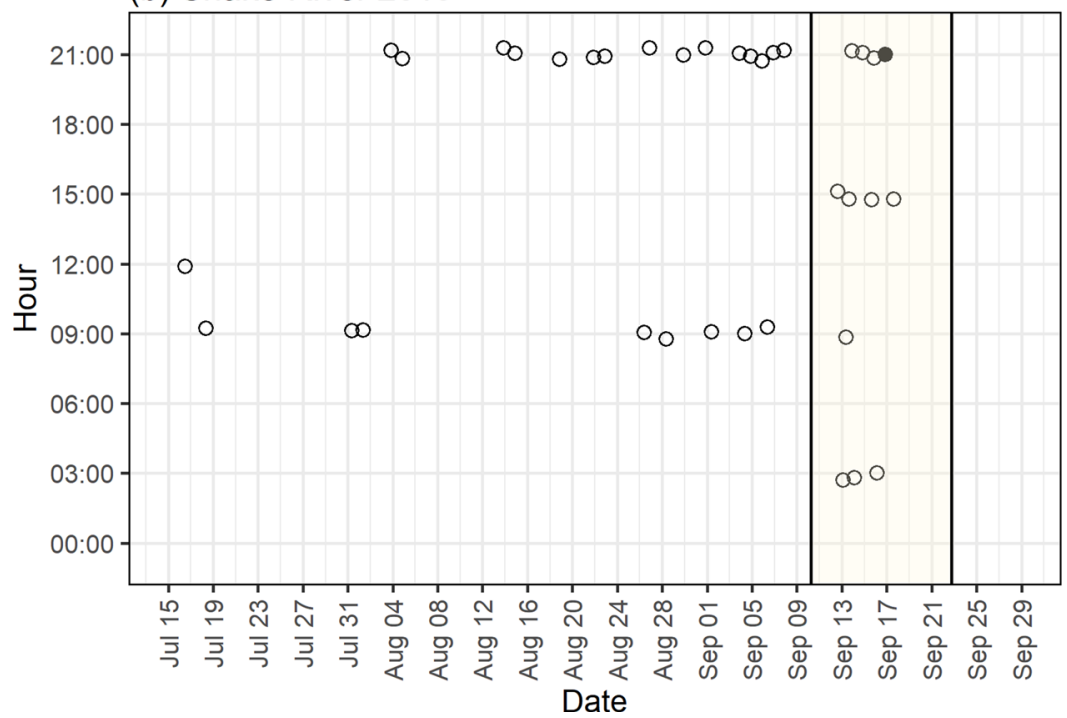

Target

- O. nerka

- T. bryosalmonae

Figure 4. Temporal distribution of positive detections from ESP samples collected from two locations in the Yellowstone River in 2018 (a) and one location in the Snake River in 2019 (b). S. japonicas slurry introductions to Yellowstone River locations are indicated by the vertical line on Aug 27. S. japonicas and T. bryosalmonae DNA were detected at Yellowstone River locations and O. nerka and T. bryosalmonae DNA were detect at the Snake River. Shaded areas indicate time period when samples were collected every $3 \mathrm{~h} \mathrm{(a)} \mathrm{or} 4 \mathrm{~h}$ (b) rather than every $12 \mathrm{~h}$.

Snake River. The ESP collected, filtered and preserved 128 field samples and technicians collected 30 manual samples. We detected T. bryosalmonae DNA in only one ESP sample and in no manual samples (Fig. 3). We did not detect dreissenid mussel DNA using either sampling approach. We detected O. nerka DNA in 35 ESP samples and 11 manual samples, though no difference was observed between the detection/non-detection of $O$. nerka DNA when comparing the ESP to manual sampling methods $(\chi 2=1.69, p=0.19, \mathrm{n}=59)$. O. nerka DNA detections from ESP samples were spread out across dates, while manual detections were clumped and often occurred on the same day (Fig. 3). In fact, manual samples failed to detect O. nerka DNA for most of August whereas the ESP had 13 detections. Higher frequency sampling (every 6 h) resulted in seven additional detections than lower frequency sampling (every 12 h; Fig. 4).

\section{Discussion}

The Upper Yellowstone and Snake rivers share similar concerns with regard to invasive species and diseasecausing organisms, as both are premier river fisheries stimulating over USD \$150 million to the local economy and serve as headwaters for a substantial portion of the United States ${ }^{17,18}$. Thus, surveillance of river health is a paramount concern. Surveillance approaches that provide early detection warnings for a broad range of taxa are especially needed since the list of potential introduced species is unbounded. Additionally, the extensive area to be monitored for invasive species makes it difficult to send technicians to all areas of concern. Technology may 
provide a solution in the form of autonomous sampling robots, capable of collecting and preserving samples, or ultimately processing those samples in real time.

We found that water samples filtered and preserved by ESPs could be used to detect the DNA of waterborne protozoa, T. bryosalmonae parasites, introduced O. nerka and even novel DNA added to the river from canned $S$. japonicas. In this study, both ESP and manually collected samples provided similar information about target DNA presence (Fig. 3). For instance, the ESP detected O. nerka DNA in 28\% (35 of 128) of Snake River samples, compared to manual methods that detected O. nerka DNA in 33\% (10 of 30) of samples. These similar detection rates are encouraging. However, the high frequency sampling enabled by the ESPs generated much more data so provided stronger weight of evidence for inferring target species presence and absence. For example, a negative ESP result provided some confidence that the target species DNA was absent, while a 'no data' result from less frequent manual sampling provides no information. If resources are available to support frequent sampling, then either method would provide similar results, especially when integrated into a probabilistic framework for modeling uncertainty in the detection of the target species DNA ${ }^{19}$.

The initial costs of the ESP, and robotic technology in general, are still large relative to human labor. But when the 'incidental' costs required for high frequency, manual sample collection are factored, the equation begins to change. For manual grab samples, collection of three field samples and one field negative control at a USGS streamgage requires an additional $2 \mathrm{~h}$ per site per visit if the sampling is part of routine USGS hydrotechnician monitoring activity ${ }^{7}$. Travel time (personnel time, per diem, gas, etc.) becomes an additional expense if eDNA surveillance is needed at a frequency greater than the 4-6 week routine monitoring schedule. Travel costs required for high frequency manual monitoring can quickly escalate in expansive areas like the western United States. High frequency surveillance by hydro-technicians would be demanding and costly to repeatedly sample a site throughout an entire season and would limit the number of sites that they could sample. Thus, we suggest that a major benefit of the ESP is the cost savings of eDNA surveillance at remote or hard to access sites.

While high-frequency sampling may better capture unique or rare events, it may not be advantageous in all situations. The two years we sampled for T. bryosalmonae on the Yellowstone and Snake Rivers were marked by extremely low abundances of this fish parasite. We detected T. bryosalmonae DNA in both manual and ESP sampled water, but the higher sampling frequency of the ESP (e.g., 2-8 times per day vs. weekly or biweekly) did not improve parasite DNA detection rates. This may be explained by the rarity of the parasite these two years.

The USGS streamgage network would be ideal to test the scalability of this robotic technology. With >8,200 streamgages nationwide, the USGS has an existing infrastructure where ESP-collected biological data could be paired with existing physio-chemical data. Ultimately, this should improve near-real time modeling and forecasting of when introduced species and pathogens are likely to become invasive or cause disease. Currently, ESP freshwater technology is still in the proof-of-concept phase and is too cumbersome and expensive (e.g., a $2 \mathrm{G}$ ESP costs $>$ USD $\$ 100,000)$ for a complete roll-out to the nation's streamgage network.

Finally, collecting samples for later return and analysis simply pushes the work and expense to a laboratory, which will be inundated with samples to process, and then only provide a look at the past, describing what organisms were detected in the past month(s). In the version of the ESP that we evaluated, there was a lengthy time lag between when a sample was collected and when it was analyzed, since the ESP must complete its entire sampling mission before filters are removed and sent to a molecular lab for analysis. The full potential of robotic technologies like the ESP will be realized when they can execute in situ analyses of water samples and transmit results to decision-makers. This near real-time analysis has been demonstrated in marine environments using in situ $\mathrm{qPCR}^{11,20,21}$, but these in situ modules are still in research and development phases. Future directions should include evaluation of this qPCR module in freshwater and development of expedient data processing software that integrates eDNA results and physio-chemical covariates collected from the USGS streamgage network. When in situ analysis becomes commonplace in environmental contexts, we will then realize the ultimate goal of timely, up-to-date information that can be used to minimize negative outcomes and improve management decision making.

\section{Data availability}

Data are available at https://www.sciencebase.gov/catalog/item/5e41ab1ce4b0edb47be63b4a

Received: 19 February 2020; Accepted: 14 August 2020

Published online: 01 September 2020

\section{References}

1. Pimentel, D., Zuniga, R. \& Morrison, D. Update on the environmental and economic costs associated with alien-invasive species in the United States. Ecol. Econ. 52, 273-288 (2005)

2. Nelson, N. M. Enumeration of potential economic costs of dreissenid mussels infestation in Montana. 1-39 (Flathead Lake Biological Station, Montana, 2019).

3. Sepulveda, A. et al. Aquatic invasive species: lessons from cancer research. The medical community's successes in fighting cancer offer a model for preventing the spread of harmful invasive species. Am. Sci. 100, 234-242 (2012).

4. Taberlet, P., Bonin, A., Zinger, L. \& Coissac, E. Environmental DNA: For Biodiversity Research and Monitoring (Oxford University Press, Oxford, 2018).

5. Sepulveda, A. J., Amberg, J. J. \& Hanson, E. Using environmental DNA to extend the window of early detection for dreissenid mussels. Manag. Biol. Invasions 10, 342-358. https://doi.org/10.3391/mbi.2019.10.2.09 (2019).

6. Erickson, R. A., Merkes, C. M. \& Mize, E. L. Sampling designs for landscape-level eDNA monitoring programs. Integr. Environ. Assess. Manag. 15, 760-771 (2019).

7. Sepulveda, A. J. et al. Adding invasive species biosurveillance to the US Geological Survey streamgage network. Ecosphere 10, e02843 (2019).

8. Scholin, C. A. et al. The quest to develop ecogenomic sensors: a 25-year history of the environmental sample processor (ESP) as a case study. Oceanography 30, 100-113 (2017). 
9. Eberts, S. M., Woodside, M. D., Landers, M. N. \& Wagner, C. R. Monitoring the pulse of our Nation's rivers and streams-the US Geological Survey streamgaging network. Report No. 2327-6932, (US Geological Survey, 2019).

10. Yamahara, K. M. et al. In-situ autonomous acquisition and preservation of marine environmental DNA using an autonomous underwater vehicle. Front. Mar. Sci. 6, 373 (2019).

11. Yamahara, K. et al. Simultaneous monitoring of faecal indicators and harmful algae using an in-situ autonomous sensor. Lett. Appl. Microbiol. 61, 130-138 (2015).

12. Sheehan, K. B., Fagg, J. A., Ferris, M. J. \& Henson, J. M. PCR detection and analysis of the free-living amoeba Naegleria in hot springs in Yellowstone and Grand Teton National Parks. Appl. Environ. Microbiol. 69, 5914-5918 (2003).

13. Hutchins, P. R., Sepulveda, A. J., Martin, R. M. \& Hopper, L. R. A probe-based quantitative PCR assay for detecting Tetracapsuloides bryosalmonae in fish tissue and environmental DNA water samples. Conserv. Genet. Resour. https://doi.org/10.1007/s12686-0170812-3 (2017).

14. Barnhart, E. P. et al. Enhanced coal-dependent methanogenesis coupled with algal biofuels: potential water recycle and carbon capture. Int. J. Coal Geol. 171, 69-75 (2017).

15. Sassoubre, L. M., Yamahara, K. M., Gardner, L. D., Block, B. A. \& Boehm, A. B. Quantification of environmental DNA (eDNA) shedding and decay rates for three marine fish. Environ. Sci. Technol. 50, 10456-10464 (2016).

16. Gingera, T. D., Bajno, R., Docker, M. F. \& Reist, J. D. Environmental DNA as a detection tool for zebra mussels Dreissena polymorpha (Pallas, 1771) at the forefront of an invasion event in Lake Winnipeg, Manitoba Canada. Manag. Biol. Invasions 8, 287-300 (2017).

17. Sage, J. L. Economic contributions of the Yellowstone River to Park County, Montana. (2016).

18. Loomis, J. The economic value of recreational fishing and boating to visitors and communities along the Upper Snake River. 97 (Colorado State University, Fort Collins, CO, 2005).

19 Stratton, C., Sepulveda, A. \& Hoegh, A. msocc: fit and analyze computationally efficient multi-scale occupancy models in R. Methods Ecol. Evol. https://doi.org/10.1111/2041-210X.13442 (2020).

20. Preston, C. M. et al. Underwater application of quantitative PCR on an ocean mooring. PLoS ONE 6, e22522 (2011).

21. Ussler, W. III. et al. Autonomous application of quantitative PCR in the deep sea: in situ surveys of aerobic methanotrophs using the deep-sea environmental sample processor. Environ. Sci. Technol. 47, 9339-9346 (2013).

\section{Acknowledgements}

This work was supported by the USGS Ecosystems Mission Area, the USGS National Innovation Center and the USGS/NPS Water Quality Partnership Program. We thank Stacie Kageyama, Tariq Tajjioui, and Craig Jackson (USGS) for extracting DNA and optimizing assays; Patrick Hutchins, Anna Swigris, Meghan Fortschen, Maddie McKeefry, Zachary Eddy, George Platt, James Johnsen and Ryan Moore (USGS) for study preparation and data collection; and Scott Jensen and Chris Preston (MBARI) for help during deployment/recovery of the ESP. We thank the Bureau of Reclamation Palisades Dam, Center for Biofilm Engineering, Teton Conservation District and Teton County Weed and Pest District for providing facilities for ESP setup and deployment. Any use of trade, firm, or product names is for descriptive purposes only and does not imply endorsement by the U.S. Government.

\section{Author contributions}

A.S., J.B., E.B., K.Y., C.M., and R.M. conceived the ideas and designed methodology; A.S., J.B., E.B., K.Y., C.B., C.S., S.K., P.W., and R.M. collected the data; A.S., C.M., K.Y. processed and analyzed the data. All authors contributed critically to the drafts and gave final approval for publications.

\section{Competing interests}

The authors declare no competing interests.

\section{Additional information}

Correspondence and requests for materials should be addressed to A.J.S.

Reprints and permissions information is available at www.nature.com/reprints.

Publisher's note Springer Nature remains neutral with regard to jurisdictional claims in published maps and institutional affiliations.

(c) (i) Open Access This article is licensed under a Creative Commons Attribution 4.0 International License, which permits use, sharing, adaptation, distribution and reproduction in any medium or format, as long as you give appropriate credit to the original author(s) and the source, provide a link to the Creative Commons licence, and indicate if changes were made. The images or other third party material in this article are included in the article's Creative Commons licence, unless indicated otherwise in a credit line to the material. If material is not included in the article's Creative Commons licence and your intended use is not permitted by statutory regulation or exceeds the permitted use, you will need to obtain permission directly from the copyright holder. To view a copy of this licence, visit http://creativecommons.org/licenses/by/4.0/.

This is a U.S. Government work and not under copyright protection in the US; foreign copyright protection may apply 2020 